\title{
Bluetongue disease in small ruminants in south western Ethiopia: cross-sectional sero-epidemiological study
}

\author{
Temesgen Abera ${ }^{1}$, Molalegne Bitew ${ }^{2^{*}} \mathbb{0}$, Debebe Gebre ${ }^{1}$, Yosef Mamo ${ }^{1}$, Yosef Deneke ${ }^{1}$ and Sukdeb Nandi ${ }^{3}$
}

\begin{abstract}
Objective: The status of bluetongue disease, vectors for transmission of the disease and the serotypes involved are not clearly known in Ethiopia. This sero-epidemiological study was conducted to determine the seroprevalence and associated risk factors of bluetongue in small ruminants of South Western Ethiopia.

Result: 422 serum samples were screened for the presence of bluetongue virus (BTV) specific antibodies using competitive enzyme-linked immunosorbent assay (c-ELISA) and 30.6\% (129/422) (confidence interval Cl 26.2-35\%) of the sheep and goat serum samples were found positive. Multivariate analysis of several risk factors like age, sex, altitude, body condition and species of animals were studied and it was observed that species of animals, age and altitude had significant influence $(P<0.05)$ on seropositivity to BTV. Goats showed more seropositivity to bluetongue as compared to sheep $[A O R=2.4,95 \% \mathrm{Cl}(1.5-3.9), \mathrm{P}=0.001]$, adult animals were more seropositive $[\mathrm{AOR}=3.1,95 \% \mathrm{Cl}(1.9-5.1)$, $P=0.001]$ than other age groups and animals at the lowland $[A O R=3.1,95 \% \mathrm{Cl}(1.5-6.4), P=0.002]$ showed more seropositivity to bluetongue than midland and high land. Sex and body condition of the animals had no statistically significant $(P>0.05)$ effect on seropositivity to bluetongue.
\end{abstract}

Keywords: Bluetongue, c-ELISA, Risk factors, South West Ethiopia, Seroprevalence, Small ruminants

\section{Introduction}

Bluetongue (BT) is an infectious and non-contagious arthropod borne viral disease of domestic and wild ruminants [1]. Bluetongue virus is a member of the genus Orbivirus in the family Reoviridae. Its genome consists of ten double-stranded (ds) RNA segments coding for seven structural proteins (VP1-VP7) and four non-structural proteins (NS1-NS3 or NS3A, and NS4). At present 27 serotypes have been reported throughout the world [2, 3].

Bluetongue is endemic primarily in the tropical and subtropical regions between the latitudes of $40^{\circ} \mathrm{N}$ and $35^{\circ} \mathrm{S}$ where vectors (Culicoides spp.) are present. In Africa, Bluetongue has been known in South Africa for over a hundred years [4] and to date 21 of the 27 known BTV serotypes have been isolated from sheep [5]. The

\footnotetext{
*Correspondence: molalegne23@yahoo.com

2 Ethiopian Biotechnology Institute, P.O. Box: 32853, Addis Ababa, Ethiopia

Full list of author information is available at the end of the article
}

major vector in Africa is considered to be C. imicola. The incursion of BTV serotype 2 into North Africa (Algeria, Libya, Morocco and Tunisia) has been confirmed in 2004 [6]. However, in Eastern Africa the information about the prevalence of bluetongue is still unclear. Toye et al. [7] in western Kenya reported the highest seroprevalence (94.2\%) of bluetongue in cattle and detected nine different serotypes (BTV 1, 3, 7, 12,15,16, 19, 22 and 24) by real time PCR.

Ethiopia is endowed with huge livestock population including 53.99 million cattle, 25.5 million sheep and 24.06 million goats [8]. Albeit with this huge potential, the status of bluetongue disease and vectors involved in the transmission in Ethiopia has not been well explored. This could be due to the fact that bluetongue disease is misdiagnosed with other highly prevalent ruminant diseases having similar clinical signs. However, 46.67\% sheep from different agro-climatic areas of central Ethiopia [9] and 34.1\% sheep of Amhara National Regional State, Northwestern Ethiopia were found seropositive 
to bluetongue based on competition ELISA [10]. These reports focused only on sheep and covering small agroecological area vis-à-vis huge livestock population and larger size of the country. Besides, virus isolation and characterization at serotype and molecular level had never been attempted. At present there is no vaccination program for control of bluetongue in small ruminants has been implemented in the country. Keeping in view of the above facts, the present study has been carried out to have a clear picture about the bluetongue disease in south western Ethiopia.

This study was the part of the bluetongue virus survey of the whole country and undertaken with the objectives to determine the seroprevalence of bluetongue in sheep and goats in selected districts in south western Ethiopia and identify the potential risk factors associated with the seroprevalence.

\section{Main text \\ Methods \\ Study area}

Study was conducted in selected districts of south western Ethiopia namely Jimma town, Bonga town and Bedele district. From each district statistically representative peasant associations (PA) were selected like Shobe, Sidisa, Qare and Yabela from Bedele, Ifa Bula, Bore and Qofe from Jimma and Bonga zuria 01 and 03 from Bonga were selected (Fig. 1).

\section{Study animals}

The study animals were small ruminants at different agro-ecological zones found in different peasant association of selected districts.

\section{Study design and period}

A cross-sectional study was conducted to estimate the seroprevalence of bluetongue virus (BTV) from December, 2015 to August, 2016 in small ruminants at south western Ethiopia.

\section{Sample size determination}

The sample size was determined according to Thrusfield [11] with $95 \%$ confidence interval and 5\% absolute precision. There was no previous research work done in the study area so that the expected prevalence rate was taken as $50 \%$. Therefore, 384 small ruminants were obtained for the study using the formula. However, to increase precision of the result, a total of 422 animals (248 sheep and 174 goats) were included. From each district samples were taken proportional to the total study population in the study districts of which (141 from Jimma district, 101 from Bonga district and 180 from Bedele district).

$$
N=1.96^{2} P \exp (1-P \exp ) / d^{2}
$$

where, $\mathrm{N}=$ sample size, $\mathrm{P}$ exp $=$ expected prevalence, and $\mathrm{d}=$ desired absolute precision.

\section{Sampling technique}

Convenience sampling was used to select study districts from different agro-ecological zones whereas simple random sampling was used to select specific animals for sampling frame and PAs. Body condition scores and age determination were done according to Vatta et al. [12].

\section{Sample collection and testing}

About $5 \mathrm{ml}$ of blood was collected aseptically from the jugular vein of each sheep and goat using plain serum vacutainer tubes and needles. The blood was allowed to clot for $1-2 \mathrm{~h}$ at room temperature, stored horizontally overnight at $4{ }^{\circ} \mathrm{C}$ in the refrigerator and then the serum was separated. All the sera were stored at $-20^{\circ} \mathrm{C}$ and transported on ice and submitted to the National Veterinary Institute (NVI) to screen for the presence of BTV group-specific antibodies using the Bluetongue Antibody Test Kit, c-ELISA (IDvet, 310, rue Louis Pasteur-GrabelsFrance) which is based on recombinant VP7 protein. The test was performed as per the manufacturer's protocol.

\section{Data management and analysis}

The data collected has been uploaded in Microsoft Excel spread-sheet and analyzed using SPSS version 20.0 software. Associations between seroprevalence and its potential risk factors were tested in a univariable and multivariable logistic regression analysis. Finally, odds ratios and its $95 \%$ confidence interval $(\mathrm{CI})$ were calculated and risk factors with a $P$ value $<0.05$ were taken as statistically significant.

\section{Results}

In the present study, 422 serum samples from sheep (246) and goats (176) were collected and screened for the presence of BTV specific antibodies by c-ELISA. Out of 422 sera tested, 129 (30.6\%) (95\% CI 26.2-35) were found to be positive for BTV-specific antibodies (Table 1).

On the basis of univariate and multivariate logistic regression analysis, it was concluded that risk factors like sex, and body condition had no significant $(\mathrm{P}>0.05)$ impact (Table 2) whereas species, age, districts and agroecology had significant $(\mathrm{P}<0.05)$ influence on the seroprevalence of bluetongue. It was found that goats were 2.3 times more likely to be positive to group specific BT virus antibody than sheep. Adults were three times compared to young animals and animals of lowland compared to highland areas were three times more likely to be seropositive to BTV respectively. Among the districts, small ruminants in Bedelle district were 2.3 times more likely to be seropositive to BTV than Jimma district (Table 2). 


\section{ETHIO_REGIONMAP}

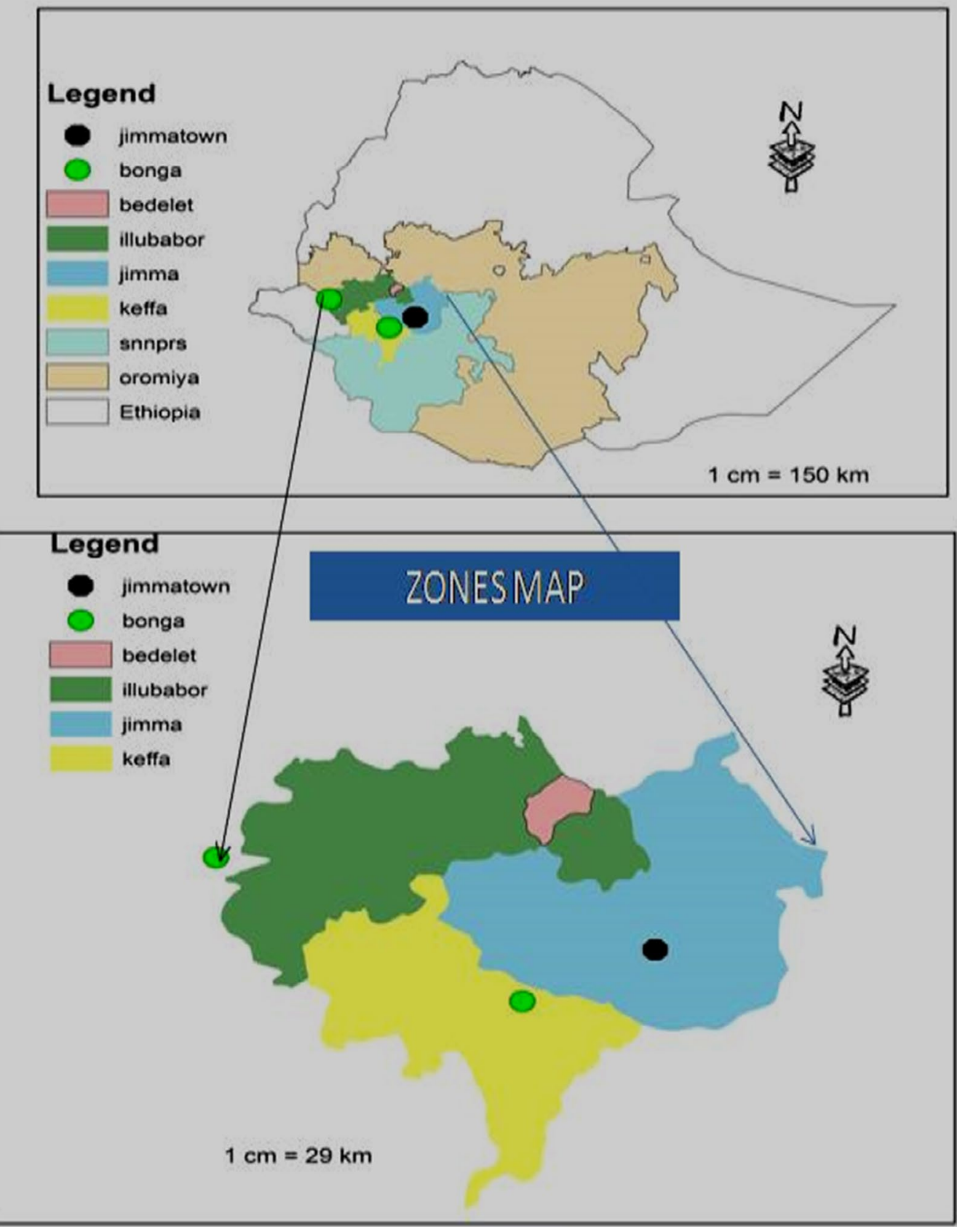

Fig. 1 Map of study area

\section{Discussions}

From this study it is revealed that antibodies to BTV is highly prevalent in sheep and goats of south west Ethiopia. The results of the present study revealed the first confirmation of BTV antibody in sheep and goats from South west Ethiopia. Although, seropositivity to bluetongue virus has been reported earlier in small ruminants in Ethiopia, it has covered only a small region without mentioning the association of risk factors [9, 10, 13]. In the present study $30.6 \%$ (129/4220 serum samples of small ruminants were found positive to antibodies to BTV. This findings is in agreement with the results of 
Table 1 Prevalence of antibodies to bluetongue virus in small ruminants from the selected PAs

\begin{tabular}{lcc}
\hline Peasant association & No. tested & $\begin{array}{c}\text { No. positive } \\
\text { (prevalence \%) }\end{array}$ \\
\hline Bonga zuria 01 & 50 & $10(20.0)$ \\
Bonga zuria 03 & 51 & $4(7.8)$ \\
Bore & 47 & $5(10.6)$ \\
Ifa bula & 47 & $10(21.3)$ \\
Qare & 45 & $14(31.1)$ \\
Qofe & 47 & $20(42.6)$ \\
Shobe & 45 & $24(53.3)$ \\
Sidisa & 47 & $24(51.1)$ \\
Yabela & 43 & $18(41.9)$ \\
Total & 422 & $129(30.6)$ \\
\hline
\end{tabular}

Table 2 Univariate and multivariate logistic regression analysis of bluetongue virus antibody in small ruminants based on different risk factors

\begin{tabular}{|c|c|c|c|c|c|}
\hline Variables & Total & Prevalence (\%) & $P$ value & OR & $95 \% \mathrm{Cl}$ \\
\hline \multicolumn{6}{|l|}{ Species } \\
\hline Sheep ${ }^{a}$ & 246 & $57(23.2)$ & - & - & - \\
\hline Goat & 176 & $72(40.9)$ & 0.001 & 2.296 & $1.505-3.500$ \\
\hline Total & 422 & $129(30.6)$ & & & \\
\hline \multicolumn{6}{|l|}{ Sex } \\
\hline Female $^{a}$ & 236 & $74(31.4)$ & - & - & - \\
\hline Male & 186 & 55 (29.6) & 0.785 & 0.919 & $0.605-1.396$ \\
\hline Total & 422 & $129(30.6)$ & & & \\
\hline \multicolumn{6}{|l|}{ Age } \\
\hline Young $^{\text {a }}$ & 181 & $33(18.3)$ & - & - & - \\
\hline Adult & 241 & $96(39.8)$ & 0.001 & 2.969 & $1.880-4.690$ \\
\hline Total & 422 & $129(30.6)$ & & & \\
\hline \multicolumn{6}{|c|}{ Body condition } \\
\hline Emaciated & 89 & $22(24.7)$ & 0.175 & 0.673 & $0.380-1.193$ \\
\hline Medium & 150 & $47(31.3)$ & 0.777 & 0.935 & $0.589-1.486$ \\
\hline Good $^{a}$ & 183 & $60(32.8)$ & - & - & - \\
\hline Total & 422 & $129(30.6)$ & & & \\
\hline \multicolumn{6}{|l|}{ Altitude } \\
\hline Lowland & 92 & $48(52.2)$ & 0.001 & 5.692 & $3.107-10.426$ \\
\hline Midland & 187 & $58(26.8)$ & 0.002 & 2.346 & $1.363-4.038$ \\
\hline Highland $^{\mathrm{a}}$ & 143 & $23(17.7)$ & - & - & - \\
\hline \multicolumn{6}{|l|}{ Districts } \\
\hline Jimma ${ }^{a}$ & 141 & $35(24.8)$ & - & - & - \\
\hline Bonga & 101 & $14(13.9)$ & 0.039 & 0.487 & $0.247-0.963$ \\
\hline Bedelle & 180 & $80(44.4)$ & 0.001 & 2.423 & $1.496-3.924$ \\
\hline Total & 422 & $129(30.6)$ & & & \\
\hline
\end{tabular}

OR Normal odds ratio

a Reference category
Gulima [10] who reported $34.1 \%$ seropositivity to BTV in indigenous sheep of Northwestern Ethiopia. The seropositivity to BTV in small ruminants $(28.6 \%)$ in India [14], domestic livestock (23\%) in Kazakhstan [15], sheep in Iran (35.9\%) [16], sheep in Iran (34.93\%) [17], goats in Iran (39.47\%) [18], small ruminants in Turkey (29.5\%) [19], sheep in Iran (37.7\%) [20] and again sheep in Iran (33.75\%) [21] has also been reported from other parts of the world.

The present finding is found to be relatively lower than the previously reported seroprevalence to BTV in small ruminants by different authors in different countries such as $41.17 \%$ in small ruminants in Southern Ethiopia [13], $46.67 \%$ in sheep in central Ethiopia [9], 78.4\% in small ruminants in Grenada [22] and $45.7 \%$ in small ruminant in India [23]. However, $30.6 \%$ seropositivity to BTV in small ruminants in the present study is comparatively higher than the reports of other researchers like $6.57 \%$ in sheep in Southeast Iran [21], 6.96\% from small ruminants (13.7\% in goats and 5.70\% in sheep) in Algeria [24], 2.63 and $5.3 \%$ in small ruminants in Kerala and Karnataka (India) $[25,26]$ respectively. In the present study, the difference in the seropositivity might be due to difference in animal species, age of sampled animals, immune status of sampled animals, agroclimatic zones, ecology, and types of culicoides vectors.

In the current study, seropositivity to BTV in goats was higher than sheep. Higher seroprevalence among goats compared to sheep indicating that goats play an pivotal role in the epidemiology of BTV. Whereas, sheep which are highly susceptible animals to BT show distinct clinical signs and die of the disease. It is also an established fact that goats with minimum clinical manifestation maintain high titer of BTV and may be the potential source of infection to other susceptible animals $[13,14]$.

It has been recorded that BT virus infection is increased with increasing age of animals and this is in agreement with the reports of Yilma and Mekonnen [13]. Assessing age as a risk factor, there was a statistically significant association $(\mathrm{P}<0.05)$ with the prevalence of BTV specific antibody in the study animals. It was shown that the younger animals started to get infected with BTV after the age of included at category of adult level. At this age, the animals are usually released into the pasture for grazing, where they are likely to be exposed to infection by vectors and subsequent BTV infection. Young age groups are usually kept indoors and are well taken care of by the owners from contracting infectious diseases, particularly the insect and tick-borne infections $[27,28]$.

This study was also assessed the effect of agro ecology on the seroprevalence of the BTV antibody and found 
that animals at low altitude are more prone to BTV infection than high altitude. This is in agreement with different authors $[18,22]$. The prevalence correlated with the probable distribution of the Culicoides vector. In addition environmental changes can influence the incidence, distribution and evolution of infectious diseases, particularly those transmitted by arthropod vectors [29].

\section{Limitations}

This manuscript is part of mega project which comprises only the serological BTV test report of the south western Ethiopia. The project is working on virus isolation, molecular characterization and identification of vectors responsible for the transmission of the disease in Ethiopia. As a limitation, this manuscript doesn't include the molecular and virus isolation data.

\section{Abbreviations}

BT: bluetongue; BTV: bluetongue virus; CSA: Central Statistical Authority; NVI: National Veterinary Institute; OR: odds ratio; Cl: confidence interval; c-ELISA: competitive enzyme-linked immunosorbent assay; AOR: adjusted odds ratio; OD: optical density; VP: viral protein; PAs: peasant associations; SPSS: Statistical Package for Social Science; RT-PCR: reverse transcriptase polymerase chain reaction

\section{Authors' contributions}

MB participated in study conception and design, solicit grant, performed data analysis, and drafted the manuscript. TA, DG and YM collected the data from the field and National Veterinary Institute (NVI), YD and SN assisted in study follow up and manuscript revision and also assisted in analysis interpretation and gave inputs in the final manuscript. All authors read and approved the final manuscript.

\section{Author details}

1 Jimma University, College of Agriculture and Veterinary Medicine, Jimma, Ethiopia. ${ }^{2}$ Ethiopian Biotechnology Institute, P.O. Box: 32853, Addis Ababa, Ethiopia. ${ }^{3}$ Virus Laboratory, Center for Animal Disease Research and Diagnosis (CADRD), Indian Veterinary Research Institute (IVRI), Izatnagar, Uttar Pradesh, 243 122, India.

\section{Acknowledgements}

The authors are thankful to Jimma University, College of Agriculture and Veterinary Medicine for the facilities provided to carry out the present work. Wubet G/Medhin at National Veterinary Institute (NVI), Ethiopia is duly acknowledged for laboratory analysis.

\section{Competing interests}

The authors declare that they have no competing interests.

\section{Availability of data and materials}

Manuscript or Additional information is available with the corresponding author on request.

\section{Consent for publication \\ Not applicable.}

\section{Ethics approval and consent to participate}

The study was approved by the ethical committees of the College of Agriculture and Veterinary Medicine, Jimma University. All animal owners were signed a letter for consent for the agreement on including of their animals in this study project.

\section{Funding}

This research work was supported by Jimma University, College of Agriculture and Veterinary Medicine, Annual Research Grant of the year 2015/16.

\section{Publisher's Note}

Springer Nature remains neutral with regard to jurisdictional claims in published maps and institutional affiliations.

Received: 6 December 2017 Accepted: 1 February 2018

Published online: 08 February 2018

\section{References}

1. Maan NS, Maan S, Belaganahalli MN, Ostlund EN, Johnson DJ, Nomikou $\mathrm{K}$, et al. Identification and differentiation of the twenty six bluetongue virus serotypes by RT-PCR amplification of the serotype-specific genome segment 2. PLoS ONE. 2012;7(2):e32601. https://doi.org/10.1371/journ al.pone.0032601.

2. Maan S, Maan NS, Samuel AR, Rao S, Attoui H, Mertens PP. Analysis and phylogenetic comparisons of full-length VP2 genes of the 24 bluetongue virus serotypes. J Gen Virol. 2007;88:621-30.

3. Bhanuprakash V, Indrani BK, Hosamani M, Balamurugan V, Singh RK. Bluetongue vaccines: the past, present and future. Exp Rev Vaccin. 2009;8(2):191-204.

4. Maclachlan NJ. Bluetongue: history, global epidemiology, and pathogenesis. Prev Vet Med. 2011:102:107-11.

5. Mogajane ME. Trade implications of bluetongue in Africa. Vet Ital. 2004;40(4):691-2

6. Hammami S. North Africa: a regional overview of bluetongue virus, vectors, surveillance and unique features. Vet Ital. 2004;40(3):43-6.

7. Toye PG, Batten CA, Kiara H, Henstock MR, Edwards L, Thumbi S, et al. Bluetongue and epizootic haemorrhagic disease virus in local breeds of cattle in Kenya. Res Vet Sci. 2013;94(3):769-73.

8. CSA. Federal Democratic Republic of Ethiopia central statistical agency agricultural sample survey, vol II Report on livestock and livestock Characteristics. 2013; pp. 15-25.

9. Woldemeskel M, Tilahun G, Tibbo M. Potgieter LN Prevalence of bluetongue virus antibodies in sheep in central Ethiopia. DtschTierarztl Wochenschr. 2000;107(10):408-10.

10. Gulima D. Seroepidemiological study of bluetongue in indigenous sheep in selected districts of Amhara National Regional State, north western Ethiopia. Ethiop Vet J. 2009;13(1):1-15.

11. Thrusfield M. Veterinary epidemiology. 2nd ed. Oxford: Black Well Science; 2005. p. 180.

12. Vatta AF, Abbot MA, Villiers JF, Gumede SA, Harrison LJS, Krecek RC, et al. Goat Keepers' Animal Health Care Manual. Agricultural Research Council. Onderstepoort: Onderstepoort Veterinary Institute with KwaZulu-Natal Department of Agriculture and Environment; 2006. p. 60.

13. Yilma M, Mekonnen M. Competitive enzyme linked immuno-sorbent assay (C-ELISA) based sero-prevalence of bluetongue virus (BTV) on small ruminants in selected areas of Wolyita, Southern Ethiopia. Virol mycol. 2015;4:148

14. Bitew M, Nandi S, Ravishankar C, Somvanshi R. Serological and molecular evidence of bluetongue in sheep and goats in Uttar Pradesh, India. African J Biotechnol. 2013;12(19):2699-705.

15. Lundervold M, Milner-Gulland EJ, O'Callaghan CJ, Hamblin C. First evidence of bluetongue virus in Kazakhstan. Vet Microbiol. 2003;92:281-7.

16. Hasanpour A, Najafi MS, Khakpour M. Seroprevalence of bluetongue virus infection in sheep in Tekab area in Iran. Indian J Funda Appl Life Sci. 2014:4(3):634-40.

17. Khezri M, Azimi SM. Epidemiological investigation of bluetongue virus antibodies in Sheep in Iran. Vet World. 2013;6(3):122-5.

18. Khalid HS, Lath MS, Abdul-Rasoul MN, Mahir HH. A serological surveillance of bluetongue disease in sheep and goats in Iraq by using competitive ELISA Technique. In: Proceeding of the eleventh veterinary scientific conference. 2012; pp. 89-94. 
19. Gur S. A serologic investigation of blue tongue virus (BTV) in cattle, sheep and gazella subgutturosa subgutturosa in southeastern Turkey. Trop Anim Health Prod. 2008;40:217-21.

20. Shoorijeh SJ, Ramin AG, Maclachlan NJ, Osburn BI, Tamadon A, Behzadi MA, et al. High seroprevalence of bluetongue virus infection in sheep flocks in West Azerbaijan, Iran. Comp Immuno Micro Inf Dis. 2010;33:243-7.

21. Khezri M, Azimi SM. Seroprevalence of bluetongue disease in sheep in West and North west Provinces of Iran. Vet Res Forum. 2016:4(3):195-8.

22. Sharma RN, Beckford S, Tiwari K, Vinet E, Thomas D, de Allie C, et al. Seroprevalence of bluetongue virus antibody in ruminants from Grenada. Open J Vet Med. 2016;6:99-103.

23. Sreenivasulu D, Subba Rao MV, Reddy YN. Overview of bluetongue disease, viruses, vectors, surveillance and unique features: the Indian subcontinent and adjacent regions. Vet Ital. 2004;40:73-7.
24. Moustafa K, Pam DL, Meriem HB. Sero-epidemiology of bluetongue in Algerian ruminants. African J Biotechnol. 2016;15:868-71.

25. Ravishankar C, Nair GK, Mini M, Jayaprakasan V. Seroprevalence of bluetongue virus antibodies in sheep and goats in Kerala State, India. Rev Sci Technol. 2005;24(3):953-8.

26. Doddamani RS, HariBabu Y. Study of prevalence of bluetongue in sheep and goats in north Karnataka. Tamil Nadu J Vet Anim Sci. 2006;2:229-33.

27. Radostits OM, Gay C, Hinchcliff KW, Constable PD. A textbook of the diseases of cattle, horses, sheep, pigs and goats. Veterinary medicine. 10th ed. London: Saunders; 2007. p. 1548-51.

28. Aradaib IE, Schore CE, Cullor JS, Osburn BI. A nested PCR for detection of North American isolates of BTV based on NS1 genome sequence analysis of BTV-17. Vet Microbiol. 1998;59:99-108.

29. Jimenez-Clavero MÁ. Animal viral diseases and global change: bluetongue and West Nile fever as paradigms. Front Genet. 2012;3:105.

\section{Submit your next manuscript to BioMed Central and we will help you at every step:}

- We accept pre-submission inquiries

- Our selector tool helps you to find the most relevant journal

- We provide round the clock customer support

- Convenient online submission

- Thorough peer review

- Inclusion in PubMed and all major indexing services

- Maximum visibility for your research

Submit your manuscript at www.biomedcentral.com/submit

() Biomed Central 